\title{
Multiple cropping systems as drivers for providing multiple ecosystem services: from concepts to design
}

\author{
Sabrina Gaba • Françoise Lescourret • Simon Boudsocq • Jérôme Enjalbert • \\ Philippe Hinsinger • Etienne-Pascal Journet • Marie-Laure Navas • Jacques Wery • \\ Gaetan Louarn • Eric Malézieux • Elise Pelzer • Marion Prudent • Harry Ozier-Lafontaine
}

Accepted: 20 November 2014 / Published online: 19 December 2014

(C) INRA and Springer-Verlag France 2014 review examples of multiple cropping systems that aim to use biotic interactions to reduce chemical inputs and provide more ecosystem services than just provisioning. Our main findings are the identification of underlying ecological processes and management strategies related to the provision of pairs of ecosystem services namely food production and a regulation service. We also found gaps between ecological knowledge and the constraints of agricultural practices in taking account of the interactions and possible trade-offs between multiple ecosystem services as well as socioeconomic constraints. We present guidelines for the design of multiple cropping systems combining ecological, agricultural, and genetic concepts and approaches.

Keywords Agroecology $\cdot$ Ecosystem services · Biotic interactions $\cdot$ Plant associations $\cdot$ Cropping systems

\section{M.-L. Navas}

Montpellier SupAgro, Centre d'Ecologie Fonctionnelle et Evolutive, UMR 5175, 1919 Route de Mende, 34293 Montpellier, Cedex 5, France

\section{J. Wery}

Montpellier SupAgro, UMR System, 2 Place Viala,

34060 Montpellier Cedex 2, France

G. Louarn

INRA, UR4 URP3F, BP6, 86600 Lusignan, France

E. Malézieux

CIRAD, UR HortSys, 34090 Montpellier Cedex 5, France

E. Pelzer

INRA, UMR 211 Agronomie, 78850 Thiverval-Grignon, France

H. Ozier-Lafontaine

INRA, UR 1321 ASTRO Agrosystèmes Tropicaux, 97170 Petit-Bourg, France 


\section{Contents}

1 Introduction $\ldots \ldots \ldots \ldots \ldots \ldots \ldots \ldots \ldots \ldots \ldots$

2 Plant diversity in multiple cropping systems. . . . . . . . .

3 From biodiversity to ecosystem services ..........

4 Multiple cropping systems and ecosystem services .....

4.1 Multiple cropping to reduce the consumption of fertilizers and water . . . . . . . . . . . .

4.2 Multiple cropping systems to reduce the use of pesticides. ................

4.3 Multiple cropping systems to reduce environmental

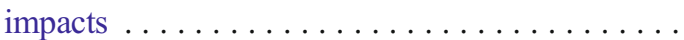

5 Guidelines for designing multiple cropping systems. . . . .

5.1 Step 1: Identification of a set of services and associated functions $\ldots \ldots \ldots \ldots \ldots \ldots \ldots$

6 Step 2: Selection of species according to the targeted functions $\ldots \ldots \ldots \ldots \ldots \ldots \ldots \ldots \ldots \ldots \ldots \ldots \ldots$

7 Step 3: How can spatiotemporal arrangement and management improve ecosystem functions and the delivery of services? ......................

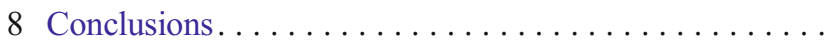

\section{Introduction}

Over the recent decades, agriculture has focused increasingly on the delivery of provisioning services such as food, fiber, and fuel, paying little attention to other important ecosystem services. This has led to intensive systems relying on the use of massive amounts of agrochemicals with a limited number of genetically improved species and cultivars, thus reducing the cultivated biodiversity. There is increasing evidence worldwide that such intensive agroecosystems have harmful effects, leading to a decline in biodiversity and threatening the environment (Tilman et al. 2001; Cassman et al. 2003). The challenge of agriculture today is to contribute to current and future food security while preserving farmland biodiversity and limiting the adverse effects on the environment or even producing other ecosystem services. Significant changes in practices and policies are needed to support this shift from farming practices aiming to deliver a single provisioning service to practices that deliver a range of services (Robertson and Swinton 2005). One suggestion is to increase the complexity of agroecosystems by increasing cultivated biodiversity (Altieri and Rosset 1995), assuming that biotic interactions could provide the functions required by the systems to enhance soil fertility without external inputs and protect crops against pests and weeds while ensuring adequate crop productivity (Doré et al. 2011; Ekström and Ekbom 2011; Bommarco et al. 2013; Gaba et al. 2014).

In multiple cropping systems, plant diversity is designed and managed to improve crop production and reduce harmful environmental impacts based on the hypothesis that positive interactions between plants for resource acquisition and mobilization of natural regulation can replace agrochemical inputs (Malézieux et al. 2009). Plant diversity can provide a range of ecosystem services based on the type (positive, neutral, or negative) and degree of plant-plant interactions and on the local environmental and management conditions (Tilman 1999; Diaz et al 2006). Attempts have been made to quantify the links between biodiversity and ecosystem services (De Bello et al. 2010; Cardinale et al. 2012; Balvanera et al. 2006), and several conceptual frameworks have been proposed recently to link biodiversity to ecosystem functioning (Diaz et al. 2013). To move forward, we now need to understand and formalize this relationship which is not straightforward (Mace et al. 2012). The delivery of ecosystem services depends largely on the interaction between biodiversity and local environmental conditions, which affect ecosystem functioning, and on socioeconomic conditions which determine the ecosystem services that are targeted and their target values. The main challenge for the transition toward a more sustainable agriculture is to determine the plant diversity and associated management practices that could deliver a set of targeted services in given environmental and socioeconomic conditions.

Multiple cropping systems can produce crops at the same time as providing several ecosystem functions in the same space. Although biodiversity in agroecosystems can be based on a mixture of ligneous and herbaceous species, with life spans varying from a few weeks to several decades, this paper focuses on cropping systems that are based on annual herbaceous plants, which are grown primarily to produce grain (cereals, legumes, oil crops, etc.) for food and feed. It addresses the main ecological processes underlying the functioning of multiple cropping systems based on annual crops and discusses how the selection of appropriate species, the spatiotemporal arrangement, and the associated agricultural practices can ensure and enhance specific functions to provide the ecosystem services targeted. It proposes a classification of multiple cropping systems based on their composition and spatiotemporal arrangement. It then analyzes the ecological processes and management strategies that are fundamental to the functioning of multiple cropping systems based on a literature review. Finally, it suggests how agroecological engineering can link the ecosystem services targeted to multiple cropping systems to provide guidelines for future land management strategies and agricultural policies.

\section{Plant diversity in multiple cropping systems}

Multiple cropping systems consist of growing two or more cultivars or species with a spatial and temporal association. Many studies have classified these systems on the basis of their species composition, design, and management (Andrews 
and Kassam 1976; Poveda et al. 2008; Malézieux et al. 2009; Lithourgidis et al. 2011). This paper focuses on plant diversity in fields and field margins in cropping systems based on annual and herbaceous plants (Figs. 1 and 2) and proposes a classification based on three distinct spatiotemporal arrangements which can be combined (Fig. 3).

In group A, plants are cultivated simultaneously in the field during the growing season, with one crop a year in temperate regions and two or three in humid tropical regions. The cultivar or plant species are totally mixed (mixed intercropping) or arranged in alternate rows or in strips (row intercropping) (Ghaley et al. 2005; Pelzer et al. 2012). The number of associated plant species or cultivars can vary, but there are usually two species, such as a cereal and a legume, or two to four cultivars of the same species (Zhu et al. 2000; Mundt 2002). In group B (relay or sequential cropping), plants are not grown together at the same time but in crop sequences. Sequences may include productive plants (grain, forage) and cover crops. The aim of a "cover crop" is not to produce food, feed fodder, or fiber but to provide a service such as soil protection by ensuring that the soil is not left bare between two crops. The cover crop can share a part of its cycle with the crop as in the case of relay cropping. For example, $\mathrm{N}$-fixing species such as Cajanus cajan can be sown at the end of a maize crop cycle in humid tropical regions to combine maize grain production with a reduction in $\mathrm{N}$ fertilizer and better soil cover (Baldé et al. 2011). In group C, crops are surrounded by assemblages of plants such as sown grass strips, hedges, and trap plants that have a specific role. For example, grass strips sown on the edges of arable fields help farmland biodiversity by providing shelter and food (Marshall et al. 2006). Multiple cropping systems can, therefore, combine several species or cultivars simultaneously in the same area (group A) or in the surrounding area (group C) or sequentially in the crop sequence (group B). Apart from differences in their functions, the decision on which multiple cropping system to use depends largely on socioeconomic conditions and access to input, machinery, and labor.

\section{From biodiversity to ecosystem services}

Haines-Young and Potschin (2010) proposed a cascade model that describes the relationships between ecosystem structures and processes, ecosystem functions, and human well-being through ecosystem services, including their social and economic evaluations. Biodiversity is central to this cascade: It is not restricted to the number of species but considered in its broadest sense, covering many different aspects of the ecosystem structure and processes such as the composition of populations, communities, functional groups, and types of interactions (Haines-Young and Potschin 2010). This cascade was adapted to cover multiple cropping systems by considering the physical and biological aspects of the agroecosystem structures and processes, their interactions, and the effect of land management (Fig. 4).

Although the primary aim of multiple cropping systems is to provide provisioning services (crop production), farmers and stakeholders expect these agroecosystems to provide other key ecosystem services. These are mainly regulating services that may include pest and disease regulation, erosion control, climate regulation, and maintenance of soil fertility. Associating species or cultivars can provide functions that help to deliver these services. The delivery of services is not only affected by the number of associated species (or cultivars) but also highly dependent on the diversity of functions. The functional diversity is not linearly related to the genetic and taxonomic diversities (Isbell et al. 2011). Moreover, a
Fig. 1 The principal components of a crop field and its adjacent areas (after Greaves and Marshall (1987) and Marshall and Moonen (2002)). This paper focuses on plant diversity within the field (field core and crop edge) and the field margin strip

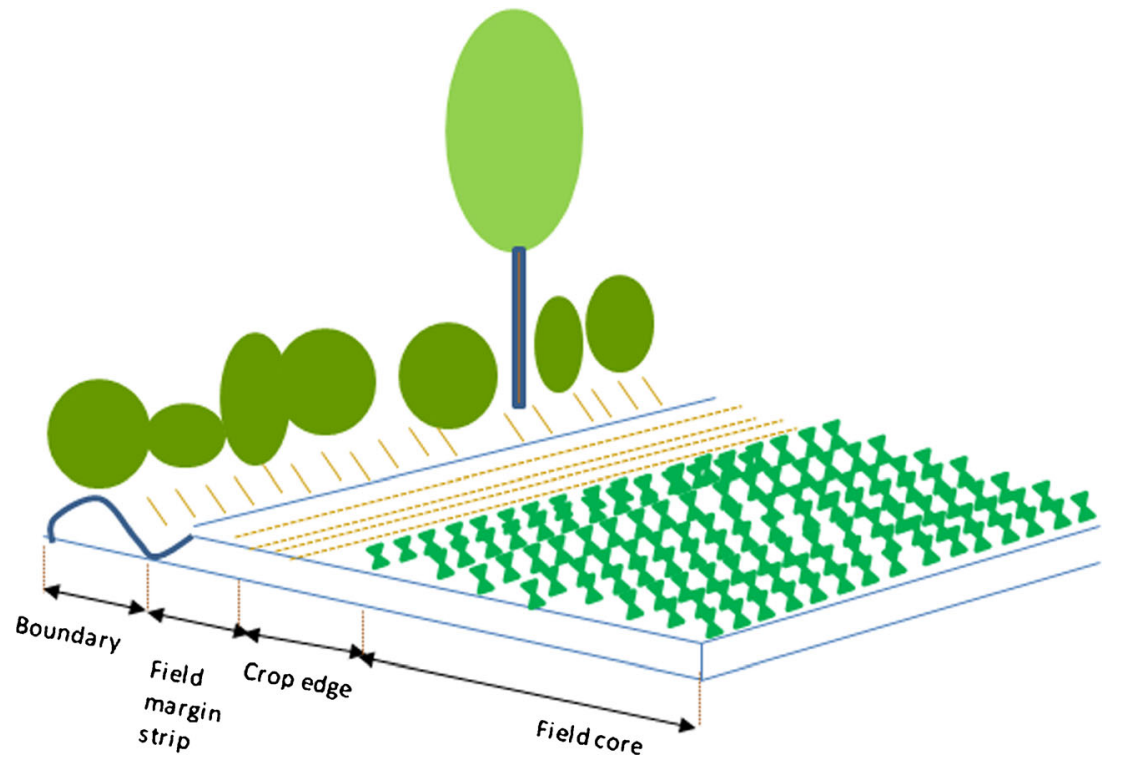

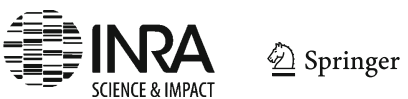


Fig. 2 Photographs of multiple cropping systems. The pictures illustrate a a vegetable farm in the Salinas Valley, California (Jacques Wery photo credits), b pea and triticale sown in a 50-50 replacement design to reduce nitrogen input (INRA UMR Agronomy photo credits), and $\mathbf{c}$ a flower strip which provides regulation services such as pollination and pest regulation (http://upload.wikimedia.org/ wikipedia/commons/5/57/ Blumen.jpg)
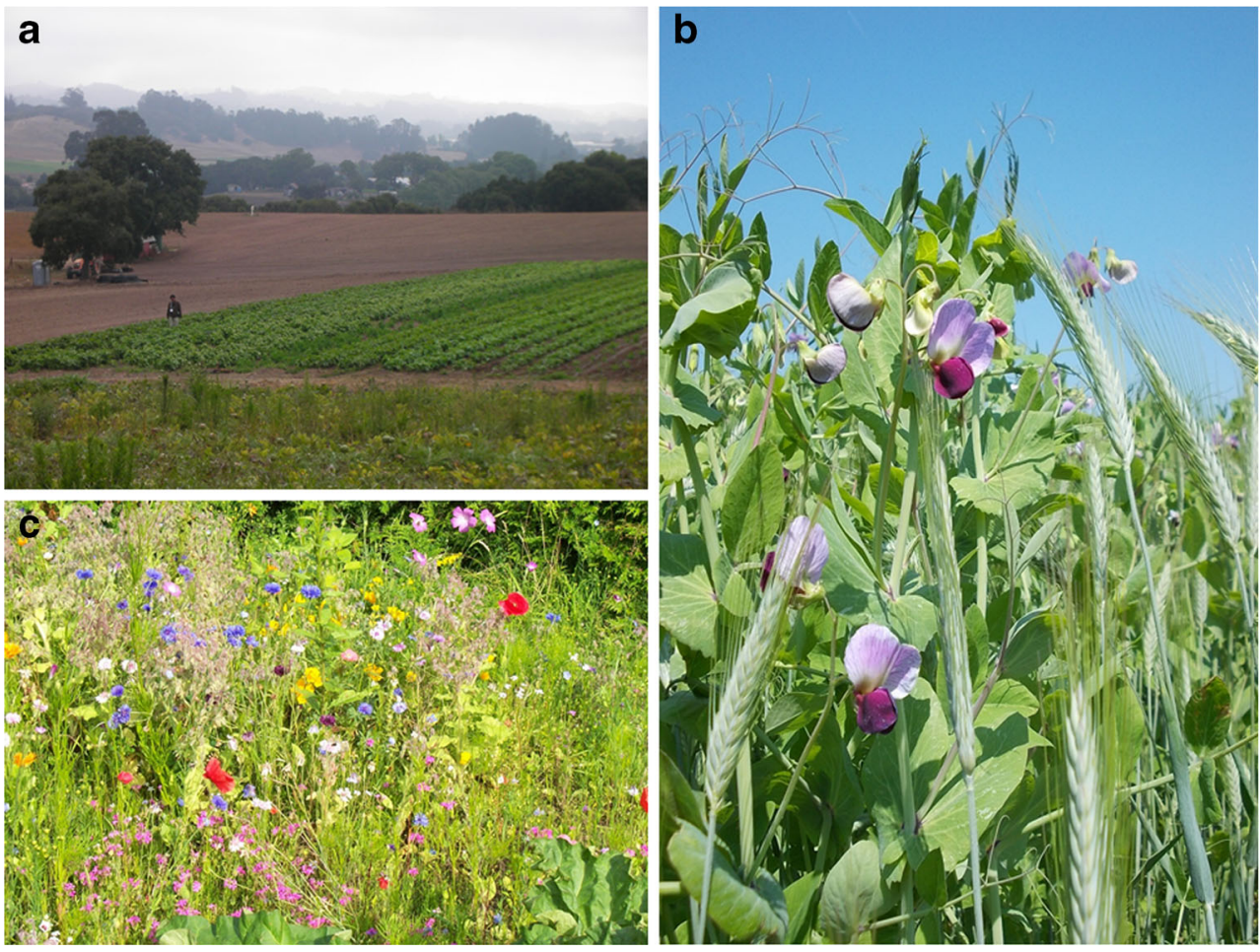

number of functions can contribute to a given ecosystem service, whereas a single function can provide a range of services (De Bello et al. 2010). Furthermore, there are important interrelationships between ecosystem services: One service can be beneficial to another (synergy), such as pollination for crop production. However, in agroecosystems, relationships between ecosystem services are often antagonistic (giving rise to the requirement for trade-offs). For instance, crop production increases with increasing use of fertilizers or pesticides, which in return causes pollution and ultimately degrades water or air quality and the biogeochemical cycles of nutrients. Land management practices such as fertilization

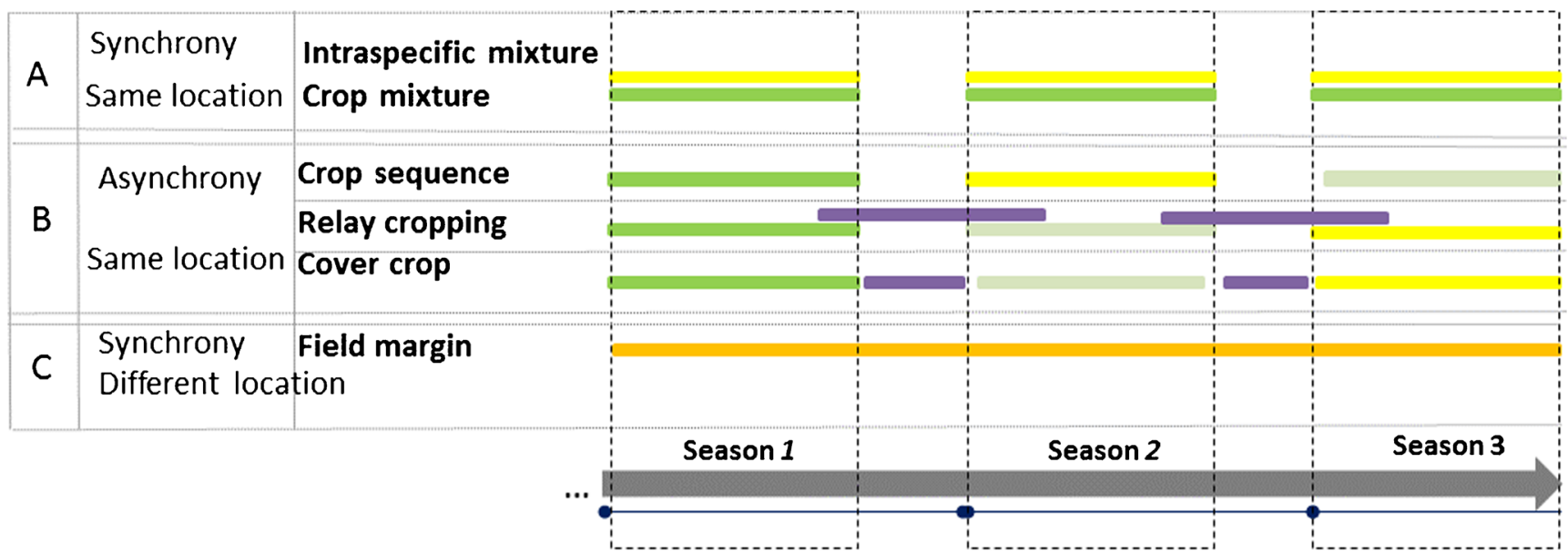

\section{Crop species 1 \\ Crop species 2 \\ Crop species 3 \\ Service species 1 \\ Service species 2}

Fig. 3 Classification of multiple cropping systems. Colored boxes show cultivars or species cultivated for grain production. Cultivars and species are differentiated by color. The black outline around a box indicates a service plant introduced in the system. Boxes with dotted lines show cultivation seasons. For simplicity, similar colors are used for species 1 and 2 across year; however, usually, crop sequences are diversified (color figure online) 


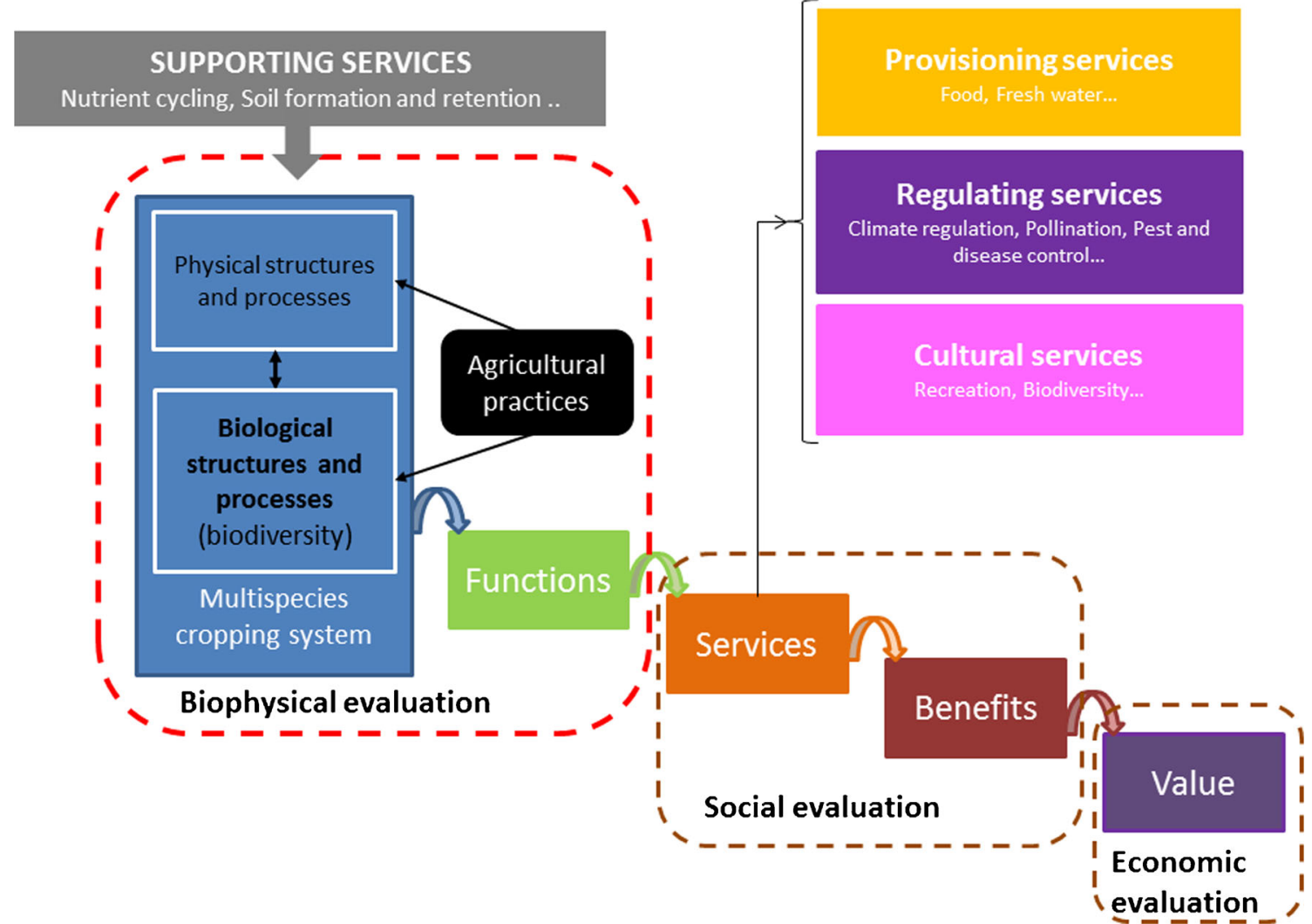

Fig. 4 Cascade of ecosystem services in agricultural systems. Adapted from Haines-Young and Potschin (2010). The classification of services is taken from the Millennium Ecosystem Assessment (2005). "Physical

or crop rotation can drive changes in one or several ecosystem services (Bennett et al. 2009).

The following sections focus on the biophysical evaluation of the system (Fig. 4, left box) and detail the ecological processes and management strategies underlying the functioning of multiple cropping systems related to provisioning services (mainly crop production) in low-input cropping systems. A set of examples of multiple cropping systems is given each function, based on a literature review.

\section{Multiple cropping systems and ecosystem services}

4.1 Multiple cropping systems to reduce the consumption of fertilizers and water

In single-species cropping systems, all individual plants have similar properties and use the same resources. As the use of external inputs, such as fertilizers and water, increases biomass production at a high resource acquisition rate, intraspecific competition can be reduced by the management of plant population density and/or planting design. Whereas singlespecies cropping systems are intended to increase the production of exported biomass in an optimized environment based on external resources, multiple cropping systems use plant structures and processes" also encompass physical and chemical structures and processes

interactions to increase crop production with lower inputs of water and nutrients. Consequently, the spatial and temporal mix of species selected for an association should use separate resources or encourage mutual growth, and/or the sowing densities and spatial arrangements should reduce competition and lessen the detrimental effects on the environment such as nitrate leaching and greenhouse gas emissions (Fig. 5).

Species may coexist when the species use different forms of a resource (complementary niches; Tilman 1990; Leibold 1995). Resource partitioning can occur when species use the same resource at different times or places (Chesson 2000), by physiological or morphological differentiation (e.g., rooting depth: Fargione and Tilman 2005; chemical form of nitrogen used: Jumpponen et al. 2002; Kahmen et al. 2006) or by resource use plasticity (Ashton et al. 2010). Complementary resource usage within a multiple cropping system requires a high functional divergence of traits related to resource use and is often related to overyielding (Hooper and Dukes 2004) and resistance to invasion by additional species (Dukes 2001). Cereal-legume associations are a well-known example of a multiple cropping system based on complementary functioning that optimizes the use of nitrogen at field scale over a growing season (Fig. 3-group A). For instance, in multisite field experiments, Hauggaard-Nielsen et al. (2009) reported that the use of total $\mathrm{N}$ resources was 30-40\% more efficient for 


\section{Reducing competition for resources}
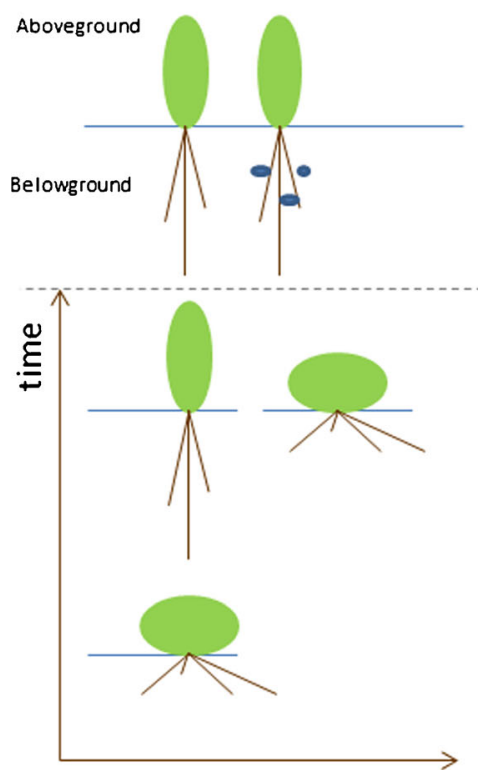

Community ecology Population dynamics Genetics

Biogeochemical niche

differentiation

(resource partitioning)

Ex: soil $\mathrm{N} /$ atmospheric $\mathrm{N}_{2}$ in

cereal/legume mixture

\section{Management strategies}

\section{Multi-species}

systems

Sowing density $\quad$ Group A
Strip arrangement

$\begin{array}{lll}\text { Spatial niche differentiation } & \text { Sowing density } & \text { Group A } \\ \text { (complementarity) } & \text { Strip arrangement } & \\ \text { Ex: superficial/deep-rooted } & \end{array}$

Temporal niche differentiation (storage effect, mass effect) Ex: cover crops

space

\author{
Sowing dates \\ Diversified crop \\ succession
}

Field margin

\section{Group B}

Group C

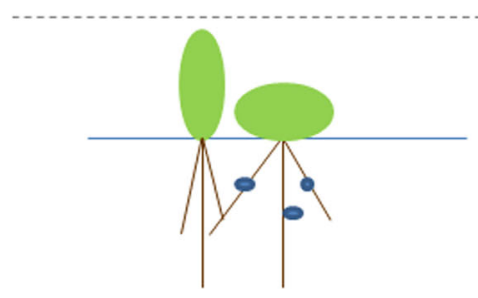
Facilitation
Ex: $P$ mobilization by
legume in crop mixture

Group A
Sowing density
Strip arrangement

Fig. 5 Schematic representation of the ecosystem functions related to resource use. The ecological processes and functions, management strategies, and multiple cropping systems as defined in Fig. 3 are shown for each function

intercropped pea and barley than for pea and barley grown as sole crop. In such systems, the cereals have a deeper, faster root system than the legume, a higher demand for $\mathrm{N}$ at the beginning of the crop cycle, and are more competitive for the soil mineral nitrogen, and so the legumes have to rely on symbiotic fixation of atmospheric nitrogen to a greater extent than when grown as a sole crop (Bedoussac and Justes 2010a, b). Furthermore, as the cereals are sown at a lower density than when grown as a sole crop, each cereal plant has access to more soil nitrogen. With the addition of little or no nitrogen fertilizer, these systems are more productive than monoculture with improved cereal growth, grain yield, and grain quality. For example, Bedoussac and Justes (2010a, b) showed that, when intercropped with winter pea with low nitrogen fertilizer input, durum wheat increased its yield by $19 \%$ and accumulated up to $32 \%$ more nitrogen than when cropped alone. However, with high nitrogen fertilizer input, these systems do not produce more than sole crops and may even produce less, because the mineral nitrogen availability is nonlimiting which changes the competitive interactions and niche differentiation, and the increased growth of the cereal may reduce the growth of the legume (Bedoussac and Justes 2010b). In an experimental system, Pelzer et al. (2012) showed that the yield of fertilized wheat (average $5.4 \mathrm{mg} \mathrm{ha}^{-1}$ ) was not significantly different from the yield of fertilized intercropped pea/wheat (average $4.5 \mathrm{mg} \mathrm{ha}^{-1}$ ), when the amount of nitrogen fertilizer applied was $140 \mathrm{~kg} \mathrm{~N} \mathrm{ha}^{-1}$ for wheat as a sole crop and $60 \mathrm{~kg} \mathrm{~N} \mathrm{ha}^{-1}$ for the pea/wheat intercrop. The yield of unfertilized wheat (average $3.9 \mathrm{mg} \mathrm{ha}^{-1}$ ) was significantly lower than that of unfertilized intercropped pea/wheat (average $4.4 \mathrm{mg} \mathrm{ha}^{-1}$ ).

Species can also coexist by facilitation where one or several species provide resources or improve the environmental conditions for the other species by modifying their local biotic and/or abiotic environment, and/or the availability of limiting resources (Callaway 1995; Brooker et al. 2008). For instance, the facilitation of water acquisition in drought conditions by hydraulic lift has been reported for species with different root system architectures (Caldwell et al. 1998 and references therein; Pang et al. 2013; Sekiya et al. 2011). Isotope labeling methods demonstrated that species with deep root systems transfer water from deeper wet soil layers to shallow dry layers, which benefits neighboring plants (in particular species 
with shallow root systems) (Dawson 1993; Sekiya and Yano 2004). Indirect modifications of plant growth resulting in deeper root profiles (Boller and Nösberger 1988), as well as microclimates (Tournebize 1995), can also lead to a more efficient use of water in multispecies systems. For example, when maize is intercropped with pigeon pea, the water use efficiency is double that of maize grown as a sole crop (Baldé et al. 2011). Moreover, positive interactions occurring between species of the same trophic level (i.e., plant species in this case) can be mediated by symbiotic microorganisms such as nitrogen-fixing bacteria, mycorrhizal fungi, and other soil biota. For instance, facilitation has been reported for nutrients such as nitrogen, for which several studies have measured the transfer from one species to the other, using ${ }^{15} \mathrm{~N}$ labeling. In cereal-legume associations (Fig. 3-group A), such flows can reach up to $20 \%$ of the nitrogen contained in the cereal derived from the legume (Hauggaard-Nielsen and Jensen 2005), which has itself been obtained by symbiotic fixation of atmospheric nitrogen by rhizobia. Most of these results were obtained in pot experiments, some of which showed that common mycorrhizal networks could contribute to a significant proportion of such plant-plant transfers ( $\mathrm{Li}$ et al. 2009). However, it is difficult to quantify such transfers in field conditions, and so the effect has not been established in the field. Facilitation may also occur for phosphorus in cereallegume associations (Fig. 3-group A). In a 4-year field experiment, intercropped maize and faba bean increased their yield by 43 and $26 \%$, respectively, on a low-phosphorus, high-nitrogen soil, compared to sole crops ( $\mathrm{Li}$ et al. 2007). Comparing solid barriers with mesh barriers between the root species of intercropped species showed that the beneficial effect of faba bean on maize was not due to seasonality or complementary use of rooting space but due to the release of organic acids and protons. However, such facilitation has mainly been reported for pot experiments (Betencourt et al. 2012). Only a small proportion of soil phosphorus is available to crops, and so legumes with greater capability to mobilize part of the large pool of unavailable phosphorus in the soil might improve the availability of this resource for the benefit of cereals in crop associations (Hinsinger et al. 2011). This relies largely on rhizosphere processes of phosphorus mobilization involving root proximity and intermingling, as shown by theoretical modeling (Raynaud et al. 2008) or proved by the experiment of Li et al. (2007): Depending on the chemical form of the resource, phosphorus uptake by maize increased from 12 to $116 \%$ through the faba bean rhizosphere processes. These were either directly affected by root activities (e.g., exudation of a phosphorus-mobilizing compound) or mediated by rhizosphere microbial activities (e.g., phosphatase activities involved in the mobilization of organic phosphorus). He et al. (2013) have recently shown in field conditions that rhizosphere microbial communities were involved in increasing the performance of cereal-legume associations.
Combining these two processes also explains the performance of multiple cropping systems such as diversified crop sequences (Fig. 3-group B). This is particularly true for systems designed to improve nutrient capture and cycling by symbiotic fixation of atmospheric nitrogen by legumes and subsequent delivery of nitrogen-rich residues to the following cereal (Peoples et al. 2009). In crop sequences including temporal grasslands, relay cropping, or using cover crops (Fig. 3-group B), the performance of the agroecosystems also depends on the priority effect, the effect on the functioning of communities of the order in which the species arrive at a site. This temporal effect is largely related to the use of resources made by the species (Körner et al. 2008), but it has proved difficult to predict this variation. This means that theoretical ecology based on niche theory faces a major challenge in understanding interactions between species and their consequences on community structure and functioning (Vannette and Fukami 2014). The priority effect has been shown to be important by recent experimental studies performed on combinations of grasses, legumes, and nonleguminous broadleaf plants which showed that the order of arrival of species has a disproportionate effect on the biomass production of the communities, compared with the effects of the sowing interval and/or plant density (von Gillhaussen et al. 2014).

In conclusion, crop production and quality in environments with low nutrient/water resource availability can be improved through ecological interactions such as facilitation of resource acquisition - at least for the benefit of one species or cultivar and complementary use of resources. However, species or cultivars must be selected to ensure that their functional traits and strategies for resource acquisition are complementary (group A). Furthermore, to optimize the use of a given resource by crops, the temporal (group B) and spatial (group C) distribution of the resource must be taken into account when selecting the association of species or cultivars.

4.2 Multiple cropping systems to reduce the use of pesticides

Multiple cropping systems can regulate pests, in the broadest sense, by preventing their growth, reproduction, or dispersal (Fig. 6). Plant composition and structural organization at field scale during the growing season (group A) or in the crop succession (group B) and at landscape scale (group C) may have direct or indirect effects on crop pests. The basic principle consists in promoting habitats that are unsuitable for pests and/or suitable for pest control auxiliaries. By selecting relevant plant species, multiple cropping systems can modify pest foraging or reproduction directly (i.e., bottom-up control) or increase the abundance of the natural enemies of the pests which are mainly insect herbivores (i.e., top-down control) (Fig. 6). 
Pest regulation

\section{Management strategies}

Multispecies

cropping

systems

Pest

(fungi, bacteria, virus...)

Regulation by antagonists

(crop beneficials...)
Group A

Group C

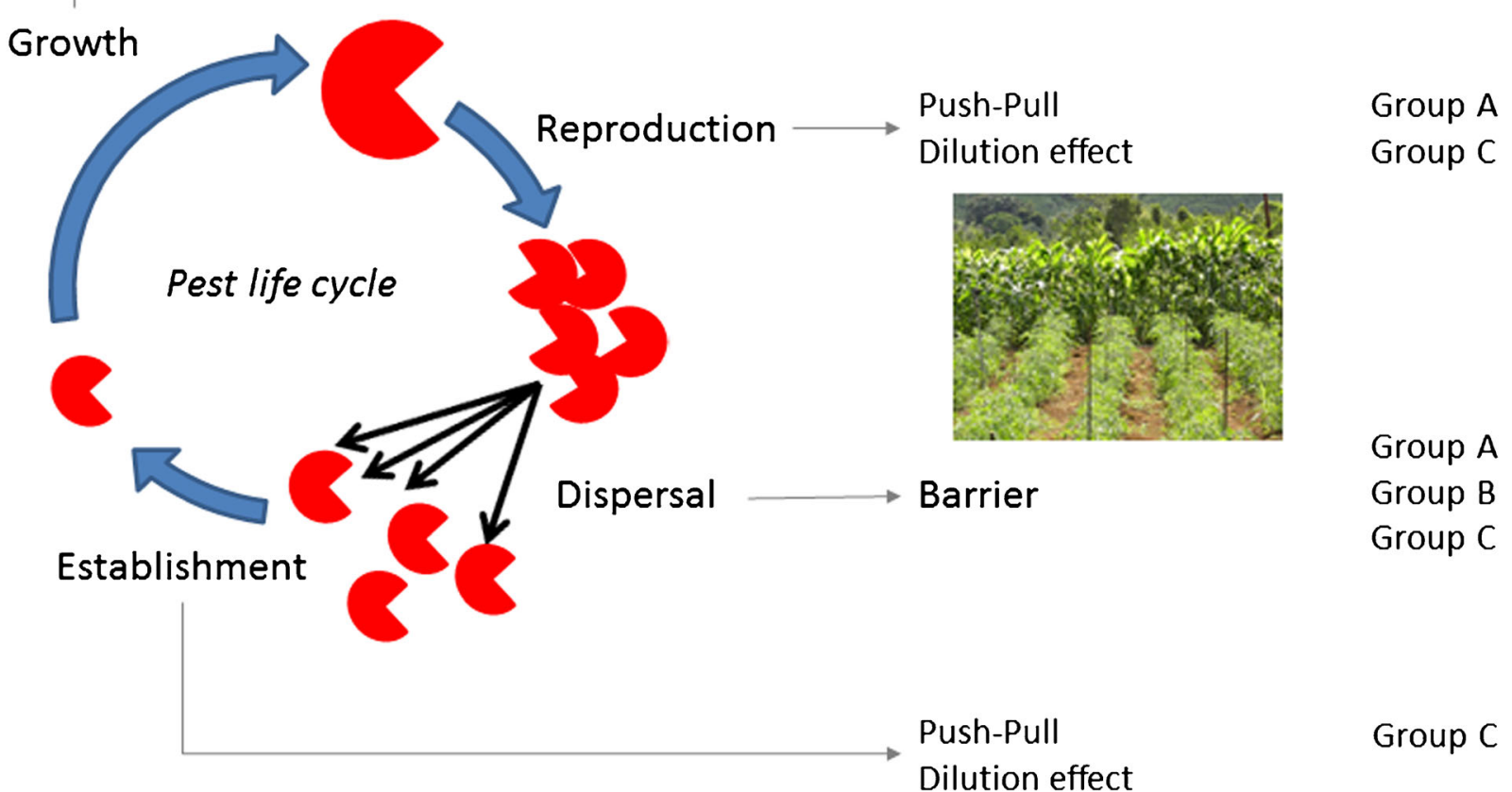

Fig. 6 Relationship between ecosystem functions related to pest regulation, management, and multiple cropping systems as defined in Fig. 3. Pest management strategies can act at different stages of the pest

life cycle. The picture illustrates a push-pull strategy (Béatrice Rhino, Cirad Martinique photo credits)

Pest dispersal and reproduction can be reduced by resource dilution and spatial disruption i.e. habitat fragmentation. Resource dilution of a host plant in the plant mixture potentially makes the pest less efficient in locating and colonizing its host (Trenbath 1993; Ratnadass et al. 2012). Resource dilution has been shown to be an appropriate means of managing many pests, such as aphids (A'Brook 1968; Smith 1976) and other phytophageous insects (Altieri 1999). Multiple cropping systems can also reduce dispersal by creating physical barriers (groups A and C) through the structure and layout of the planting scheme or by modifying the microclimates in plant associations. These physical barriers create habitat fragmentation which can prevent the spread of disease or make it difficult for insects to find food or mating sites (Francis 1990) and has been shown to be efficient at controlling airborne diseases. For instance, cereal crops can disrupt insects in their visual search for smaller crops (Ogenga-Latigo et al. 1992) or prevent dispersal by wind. Resource dilution and habitat fragmentation were both shown to contribute to the efficient control of disease in crop associations in low-

input farming, with various success stories for cereals (Zhu et al. 2000; Mundt 2002).

Pests can be reduced by life cycle disruption using crop sequences within a field (group B in Fig. 6). Diversification of crop sequences can lead to pest reduction (Bennett et al. 2012) and is critical for controlling soilborne diseases (Curl 1963; Bullock 1992). Selecting the crops in a sequence should take account of the effect of the preceding crop on the development of pests detrimental to the following crop. For example, fusarium head blight is very severe for wheat sown after maize (Pirgozliev et al. 2003). Moreover, multiple cropping systems may contain species that produce biochemical cues that disrupt the development of diseases, pests, root parasitic nematodes, and weeds (Ratnadass et al. 2012). These allelopathic effects are created mainly by the introduction of particular species into the intercrop (group A) or the crop sequence (group B). For instance, GomezRodriguez et al. (2003) reported the decrease of early blight of tomatoes in tomato-marigold intercropping due to allelopathy as well as the creation of microclimates. Cover cropping or relay cropping can also control diseases (e.g., green manure as a 
control strategy for soil borne diseases: Motisi et al. 2009) or root nematodes (Yeates 1987; Rodriguez-Cabana and Kloepper 1998) through allelopathy (Fig. 6, group B). Crop sequences including nonhost plants may reduce the inoculum of telluric pathogens such as nematodes as in the rotation of strawberry with oats (Lamondia et al. 2002) or pineapple and sugarcane with banana. Plants may have suppressive effects which lead to the reduction of soil inoculum through the emission of biocides. In Martinique, plants with biocidal properties have been shown to control bacterial wilt caused by Ralstonia solanacearum, responsible for significant losses elsewhere in the world in tomato and other vegetable crops (Deberdt et al. 2012).

Pests (Fig. 6) can be controlled using the pull or push-pull strategies. Push-pull uses repellent "push" plants to discourage pests from settling on crops and "pull" plants to attract them to neighboring plants (Cook et al. 2007; Shelton and BadenesPerez 2006). The stimuli emitted by plants may be visual, chemical, or trophic. Introducing another plant species can create a new habitat, which may ultimately also modify the populations of predators. One example of a pull strategy is trap cropping. Trap crops are planted to attract or intercept targeted insects or pathogens and prevent them from completing their life cycle, to reduce damage to the main crop (Shelton and Badenes-Perez 2006). For instance, planting alfalfa or sorghum in combination with cotton is a technique that has been widely used in Australia and the USA (Deguine et al. 2008). A pull strategy was developed to combat Chilo sacchariphagus (spotted borer), a significant sugarcane pest. Female borers were pulled to nesting sites on a trap plant, Erianthus arundinaceus, which was planted around the perimeter of the sugarcane plot achieving a $90 \%$ reduction in attacks with a $20 \%$ increase in yield (Ratnadass et al. 2013). The effects were observed up to $40 \mathrm{~m}$ from the edge of the plot (Nibouche et al. 2012). Repelling insect pests can be coupled with attracting pest predators in crop associations. Planting sunflowers in an organic vegetable cropping system increased the abundance of, and encouraged greater foraging activity by, native insectivorous birds (Jones and Sieving 2006). Other crops such as pigeon pea (Cajanus cajan), and maize and okra (Abelmoschus esculentus) attract Helicoverpa armigera, which is a pest for cotton and tomato (Pike et al. 1987). Predators such as ground beetles e.g. carabids and spiders are also attracted when fields are surrounded by hedgerows or noncropped areas (Burel and Baudry 1995). Establishing strips of weeds also encourages the development of auxiliary organisms, by increasing the nectar and pollen resources for many species of insect (Wackers et al. 2007 quoted by Deguine et al. 2008).

4.3 Multiple cropping systems to reduce environmental impacts

Intensive farming practices associated with monospecies cropping systems have had considerable harmful effects on the environment such as landscape simplification, loss of habitat for many species, increased water consumption, soil erosion and degradation, and pollution due to the extensive use of inputs use such as mineral fertilizers, fossil fuels, and pesticides (Tilman et al. 2002).

Multiple cropping systems can reduce these effects (Fig. 7). They can reduce soil erosion and the associated loss of nutrients (Dabney 1998) and act directly on soil fertility by improving soil organic matter and promoting $\mathrm{N}_{2}$ fixation by legumes. Increasing soil organic matter is also a key to preserving soil fertility (Mann 1986). It is encouraged by systems that minimize soil disturbance and maximize the retention of crop residues (mulching, Fig. 7-group B) and increased efficiency in the use of nutrients (Jarecki and Lal 2003). This can be achieved by efficient management practices such as diversifying crop successions, reducing tillage, and planting cover crops (group B) (West and Post 2002; Jarecki and Lal 2003). Furthermore, legume crops (groups A or B, as green manure) can increase $\mathrm{N}$ pools and $\mathrm{N}$ use efficiency in rotation (Drinkwater et al. 1998; Dabney et al. 2001). In a recent study in Australia, the successive introduction of no-till, cover crops, and legume breaks in the rotation increased the grain yield of wheat by about 500,1000, and $900 \mathrm{~kg} \mathrm{ha}^{-1}$, respectively, compared to the low-input baseline yield (Kirkegaard et al. 2014).

Multiple cropping systems can also help to preserve the quality of ground and drinking water. Nitrate concentration is a major concern as it is considered harmful to human health and responsible for the eutrophication of aquatic ecosystems. The amount of $\mathrm{NO}_{3}$-nitrate leached from agroecosystems appears to be greatest when there is an accumulation of nitrate in the soil profile that coincides with, or is followed by, a period of high drainage (Di and Cameron 2002). Multiple cropping systems using cover crop or relay intercropping (group B) can mitigate nitrate losses by drainage. A typical winter cover crop can, for instance, decrease $\mathrm{NO}_{3-}$ leaching by $25 \mathrm{~kg} \mathrm{~N} \mathrm{ha}^{-1}$ (Dabney et al. 2001; Dinnes et al. 2002). The main advantages of these systems over conventional crop sequences result from a combination of increased plant $\mathrm{N}$ capture throughout the year through nutrient cycling and $\mathrm{N}_{2}$ fixation, reduced $\mathrm{N}$ fertilizer input, and a gradual release of organic $\mathrm{N}$ that is often better synchronized, than fertilizer application with crop demand and microbial population dynamics. They may also have the advantage of reducing pesticide use and transfer to water (Dabney et al. 2001).

Finally, although multiple cropping systems may sometimes foster populations of undesirable organisms (e.g., slugs in cover crops, Walter et al. 1993), they generally help to increase aboveground and belowground biodiversity, improving agroecosystem regulation, and delivering an ecosystem service per se (Mace et al. 2012). Increasing functional diversity in multiple cropping systems (groups A, B, and C) promotes biodiversity in the agroecosystem and increases food 


\section{Reducing negative environmental impacts \\ Soil physics \\ Soil biogeochemistry \\ Microbial ecology \\ Chemical ecology}

\section{Management strategies \\ Multispecies \\ cropping \\ systems}

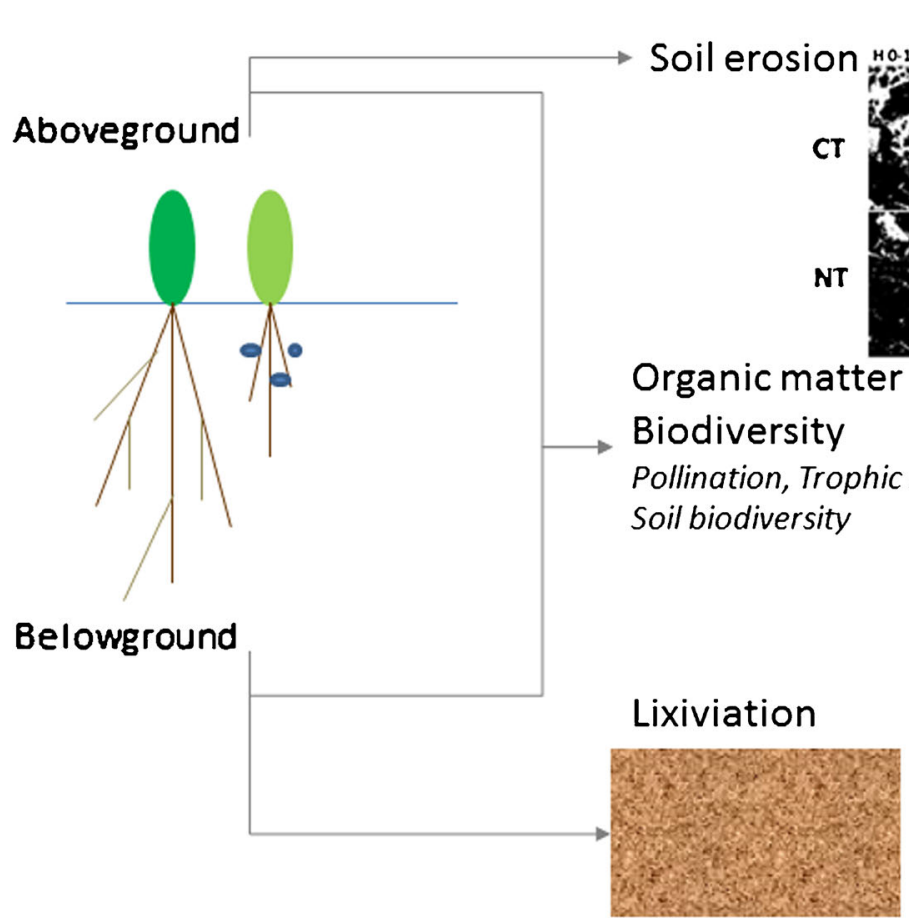

Fig. 7 Relationship between ecosystem functions for reducing environmental impacts, ecological processes, management, and multiple cropping systems as defined in Fig. 3. Pictures illustrates the porosity of soil samples obtained in conventional tillage (CT) and no-tillage (NT) (Matthieu Carof, photo credits) and lixiviation web complexity by providing new habitats for a variety of animals and soil organisms that would not be present in a single crop environment (Altieri 1999; Sokos et al. 2013). In particular, spatial diversity (group C) can maximize nesting opportunities for birds and create habitats for a range of invertebrates (Vickery et al. 2009). It can also increase the diversity and abundance of pollinators (Potts et al. 2010), which in turn may increase crop production by up to $40 \%$ (Bretagnolle and Gaba, submitted).

\section{Guidelines for designing multiple cropping systems}

Setting up multiple cropping systems to maintain crop production while significantly reducing inputs (mineral fertilizers, water, energy, and pesticides) and providing regulation and cultural services requires much more than an understanding of species coexistence and the identification of species functions. This challenge raises a number of questions: How "different" is "different enough" to allow species to coexist and increase biomass production? What is the planting density for each species to limit competition for resources and/or improve pest regulation? How should species be spatially and temporally organized? Will the delivery of ecosystem services (independently or in synergy) be improved when species are grown at the same time in a field, in sequence or in separate areas in the field and its surrounding? What agricultural practices should be used to improve the provisioning of ecosystem services? Are theoretically designed multiple cropping systems feasible in practice (availability of machinery, work organization, economical sustainability)? How can specific design methods for multiple cropping systems be set up?

These questions can only be answered by multidisciplinary research, combining quantitative genetics, community ecology, functional ecology, landscape ecology, population dynamics and agronomy, etc. Furthermore, although cropping systems share biophysical aspects with natural systems through resources, functions, and services, they also share management 
aspects with industrial systems as they are set up and managed by farmers (Le Gal et al. 2010) who can act both on their structure and on inputs/outputs, and to some extent on their internal biophysical functions, e.g., by soil tillage. The design and evaluation of multiple cropping systems must take account of this potential for optimizing management practices. Guidelines linking decision-making tools to design approaches for multiple cropping systems must be set up to reconcile the delivery of crop production and other ecosystem services (Fig. 8). The following sections propose guidelines which aim to facilitate the integration of knowledge of the biology and ecology of plant species/communities (and their associated organisms) and knowledge of the effect of farming practices, in order to design and assess multiple cropping systems for given biophysical and socioeconomic environments.

The guidelines (Fig. 8) are presented as an up-down approach using a cascade model for ecosystem services (Fig. 4), starting from the identification of a set of services to be targeted through to the structure and management of a multiple cropping system. This is based on knowledge of individual and combined plant functions, in response to abiotic and biotic conditions in interaction with agricultural practices (Fig. 4). Particular attention should be paid to biophysical relationships within the various ecosystem services, which may be positive (synergy), negative (trade-off), or neutral, and also to tradeoffs between the different aims of farmland stakeholders.
Given the complexity of the interactions and feedback processes within multiple cropping systems and the difficulty of harnessing them to provide ecosystem services, a three-step design process is proposed in which steps 2 and 3 are interrelated.

\subsection{Step 1: identification of a set of services and associated functions}

Step 1 (Fig. 8) identifies, in consultation with stakeholders, the set of priority services to be provided by the system in the short- and medium-term. These services required of the agroecosystem, together with binding constraints defined by biophysical (e.g., soil texture), social (e.g., labor), and economic (e.g., input and output prices) factors, could be organized as a set of objectives and constraints which will provide further guidance for the design and assessment of the multiple cropping system (Blazy et al. 2009). Each component of this "set of objectives and constraints," in particular each targeted ecosystem service required of the system, can be identified and evaluated in consultation with stakeholders namely farmers, local residents, industry, environmental organizations, etc. and then translated into assessment indicators, e.g., variables for quantifying the service which can be measured in field experiments (Rapidel et al. 2009) or simulated using appropriate models (Delmotte et al. 2013).

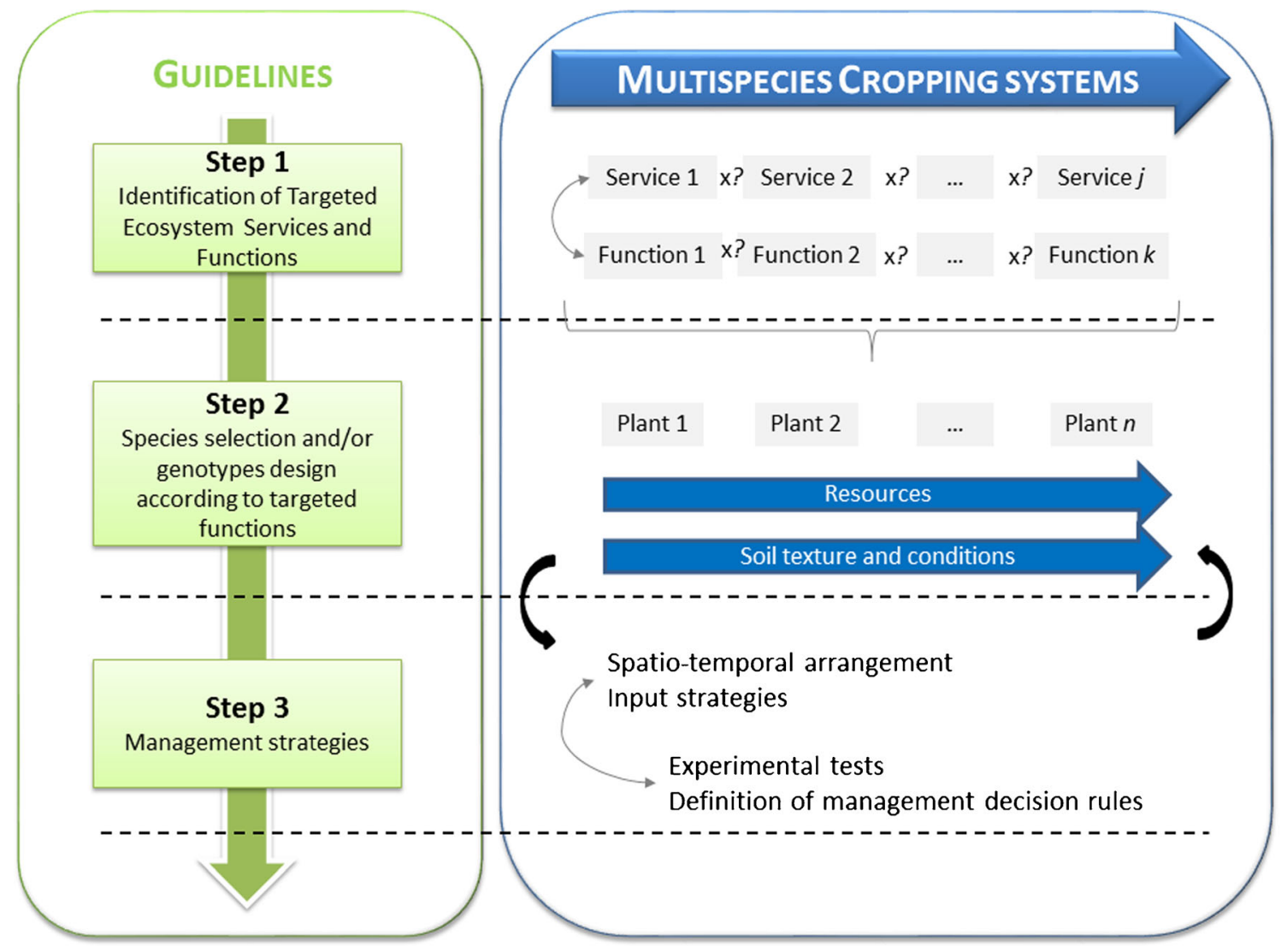

Fig. 8 Guidelines split into a three-step design process for developing sustainable multiple cropping systems. Steps 2 and 3 are interrelated 
The interactions between services must then be identified. Until now, these interactions have been studied by mapping the various ecosystem services, to identify, for example, "win-win" areas, that are of benefit to both ecosystem services and biodiversity (Naidoo and Ricketts 2006; Lavorel et al. 2011; Eigenbrod et al. 2012). However, these maps are generally built using proxies such as land cover or types of vegetation that are extrapolated from a limited number of data points to large areas (Nagendra et al. 2013). Mapping ecosystem services is not an appropriate approach for multiple cropping systems. Firstly, they are carried out at field scale, which is not relevant for ensuring the delivery of multiple services for the various stakeholders, and secondly, a description of a pattern of ecosystem functions is not sufficient to understand the links between plant diversity, plant functions, and agricultural practices, even at field scale. An ambitious interdisciplinary research effort is needed to give a comprehensive assessment of these links and the synergies and tradeoffs in ecosystem functions and their related ecosystem services. It is also necessary to determine the key individual or combined ecosystem functions that deliver these services. Ecological knowledge can be used to assess ecosystem functions (Fig. 4), e.g., the functional traits that underpin different services and their spatial distribution (Lavorel et al. 2011), in order to select species (crops or service plants) or cultivars.

\section{Step 2: selection of species according to the targeted functions}

Going further up the cascade in Fig. 4, step 2 (Fig. 8) identifies plant species whose functional characteristics can sustain the services targeted. This can be based on expert knowledge, the literature, or databases as widely proposed for grass and legume mixtures (Louarn et al. 2010 and references therein). However, these approaches are limited given the very large number of combinations of factors which have to be taken into account, as has already been found when considering composite cultivars (Miranda Filho and Chaves 1991). Furthermore, most of the available knowledge concerns the characteristics of a cultivar or a species sown as a sole crop, which is often not sufficient to predict its behavior in a multiple cropping system. It is likely that cultivar and/or species traits targeted for multiple cropping will differ from those required for single cropping systems (Lithourgidis et al. 2011). Moreover, linking plant traits to plant functions in a given multiple cropping system is not straightforward, and breeding crops for multiple cropping systems is a major challenge, as new and complex interactions need to be considered that can be formulated as " $f\left(\right.$ Species $_{1}$, Species $_{2}, \ldots$, Species $\left._{n}\right) \times($ Agricultural practices $\times$ Environment)" for species associations and as "f$\left(\right.$ Genotype $_{1}$, Genotype $_{2}, \ldots$, Genotype $\left._{n}\right) \times($ Agricultural practices $\times$ Environment)" for cultivar associations, $n$ being the number of interacting species or genotypes and $f$ being the function describing the relationship between them. Two strategies can be suggested in order to design appropriate plant-plant associations.

The first strategy is a classic screening method, assessing how a mixture of crops/varieties can meet a set of targeted ecosystem services at cropping system scale (i.e., rotation). This approach, which is "blind" to traits, is based on the statistical analysis of the ability of the plants to mix using cultivar/species associations in optimized experimental designs. It uses hybrid breeding methods and quantitative genetics and sets out to describe the general mixing ability (GMA, the mean value for all associations) and/or the specific mixing ability (SMA, the interaction between two given species or cultivars). This was first developed for cultivar mixtures (reviewed in Dawson and Goldringer 2012; Gizlice et al. 1989; Knott and Mundt 1990; Lopez and Mundt 2000), but can be extended directly to multiple cropping systems (Gallais 1970; Finckh et al. 2000; Finckh and Wolfe 2006), and temporal successions of crops, even though this has not yet been proposed. Ideotypes can be developed by quantitative trait loci (QTL) detection or genomic selection methodologies, using markers to tag the genomic areas with the greatest positive interactions between genotypes or species (complementation/ facilitation). Although this approach is attractive, it has two major limitations: (1) It can be difficult to implement as it requires midterm experiments with several replicates, and (2) only a limited set of factors, such as the effect of tillage or of nitrogen fertilization, and services can be tested.

The second strategy is a trait-based approach, where the species/cultivar assembly relies on the selection of a combination of plant functional traits, i.e., the conception and development of multispecies/cultivar ideotypes. The combination of targeted functional traits can be based on current knowledge of the relationship between traits and functions (Lavorel and Garnier 2002; Suding et al. 2008) or from a mechanistic model (Hammer et al. 2010; Lynch 2013). If a trait value/state (or a combination of trait values) is not found in an available variety/breeding line, a breeding strategy is required specifically for multiple cropping systems. This strategy should combine ecophysiological modeling of multiple cropping systems with quantitative genetics. This approach was shown to be useful for breeding for complex traits, which were broken down into physiologically relevant traits all connected to model parameters that were less sensitive to environmental conditions ( $\mathrm{Gu}$ et al. 2014). In this second strategy, the development of ideotypes can also benefit from QTL detection or genomic selection methodologies, with markers used to tag the genomic areas controlling targeted traits or parameters in ecophysiological models, e.g., vernalization or photoperiod parameters in models predicting plant earliness (Bogard et al. 2014). In this way, marker-based 
modeling can be used to predict key parameters of ecophysiological models and then build genotypes with optimum parameter combinations (Letort et al. 2008; Reymond et al. 2003; Prudent et al. 2011) through the selection of the best allelic combinations (Hoogenboom et al. 2004; Chenu et al. 2009). For all these reasons, we believe that a trait-based approach is a promising strategy for building ideotypes for multiple cropping systems, even though the main bottlenecks are still the availability of cultivar trait values and dedicated ecophysiological models.

\section{Step 3: how can spatiotemporal arrangement and management improve ecosystem functions and the delivery of services?}

After defining a set of species and conditions in step 2, the agroecosystem functioning can be optimized by management in order to give the expected combination of services defined in step 1. It can first be obtained by adjusting the spatial and temporal combination of species as proposed in the three groups in Fig. 3. Inputs (supply of water at a specific time to limit competition) and outputs (leaving straw on the soil instead of using it for animals) can then be managed, to drive the agroecosystem functions toward delivering the target set of services. The spatial arrangement of species should be planned depending on the traits and functions of the species ranging from "as close as possible" to maximize short distance synergies, e.g., nitrogen transfer between the rhizosphere of legumes and nonlegume plants, and "far enough apart" to avoid competition for resources, e.g., light and water. For example, in intercropped vineyards, the width of the intercrop strip is optimized to reach a trade-off between limiting run-off and limiting grape yield by competition for water (Ripoche et al. 2010). Similarly, the benefits of a temporal succession of species will depend on how the species affect each other and on how the agroecosystem functions. The effect of biodiversity on agroecosystem functioning may not be immediate and can often be observed in the response of species to predation, competition, or parasitism (see Gaba et al. 2014 for further details).

Input management can be adjusted to modify the resource availability, at a specific time and at a specific location in the field, to drive the system functions toward the target. For example, in strip intercropping, a limited amount of nitrogen applied to the cereal component of the association can help to maximize its grain yield without reducing nitrogen fixation by the legume. The output of the system can also be managed to achieve a compromise between exporting biomass of all species to increase the economic efficiency of the agroecosystem and keeping it in the system to provide services such as soil cover to reduce run-off and increase soil organic matter and biodiversity. This is typically the case in conservation agriculture (Giller et al. 2009).

However, the choice of spatiotemporal arrangements depends not only on biological processes but also on labor constraints, on suitable farming equipment, and on the profitability of each species, price generally being a dominant factor. Moreover, adjusting the spatial and temporal combination will affect the choice of species or cultivars which are not all suitable for a given agricultural region because of soil and climate conditions, the location, or market conditions. Decision rules should, therefore, be adapted to local environmental and production conditions and to farmers' goals in terms of production and other targeted services. Adaptive management of agricultural practices would be a relevant strategy. For instance, sowing cereals and alfalfa in a crop succession in a group B multiple cropping system to reduce nitrogen fertilization and control weeds while maintaining crop yield would only be appropriate if there was a local market for alfalfa hay. Conversely, if no local market is available, a group B multiple cropping system could be selected by sowing a cover crop between two annual crops. In this particular case, the functions relating to nitrogen use and weed control, and the life cycle of the species will be the main criteria for selecting the species. Consequently, ensuring that multiple cropping systems are successful in a wide range of locations, implies rethinking market mechanisms and organization (Horlings and Marsden 2011), and developing local markets (Berthet et al. 2014).

\section{Conclusions}

This paper considered how efficient multiple cropping systems could be implemented to provide food production as well as ecosystem services and proposed guidelines for agroecological engineering to link biodiversity of targeted ecosystem services in multiple cropping systems with a set of objectives and constraints. Several ecological processes, including biotic interactions such as facilitation, parasitism, and dilution, are involved in multiple cropping systems. This provides a wide range of opportunities for associating plant species or cultivars to deliver ecosystem functions which can be improved by management using appropriate agricultural practices, e.g., timing of inputs or crop density. However, to achieve this target, a greater understanding is required through a multidisciplinary approach combining genetics, ecology, and agricultural sciences, and market mechanisms and organization need to be reviewed.

Acknowledgments This work was supported by INRA Environment and Agronomy Division. We would like to thank the two anonymous reviewers and the editor for their helpful and constructive comments on the earlier version of our manuscript. The revised manuscript has been corrected by Tony Tebby. 


\section{References}

A'Brook J (1968) The effect of plant spacing on the numbers of aphids trapped over the groundnut crop. Ann Appl Biol 61:289-294. doi: 10.1111/j.1744-7348.1968.tb04533.x

Altieri MA (1999) Applying agroecology to enhance productivity of peasant farming systems in Latin America. Env Dev Sustain 1: 197-217. doi:10.1016/S0167-8809(99)00028-6

Altieri MA, Rosset PM (1995) Agroecology and the conversion of largescale conventional systems to sustainable management. Int J Env Stud 50:165-185. doi:10.1080/00207239608711055

Andrews DJ, Kassam AH (1976) The importance of multiple cropping in increasing world food supplies. In: Papendick RI, Sanchez A, Triplett GB (eds) Multiple cropping. ASA special publication 27. American Society of Agronomy, Madison, pp 1-10

Ashton IW, Miller AE, Bowman WD, Suding KN (2010) Niche complementarity due to plasticity in resource use: plant partitioning of chemical N forms. Ecology 91(11):3252-3260. doi:10.1890/091849.1

Baldé AB, Scopel E, Affholder F, Corbeels M, Da Silva FAM, Xavier JHV, Wery J (2011) Agronomic performance of no-tillage relay intercropping with maize under smallholder conditions in Central Brazil. Field Crops Res 124:240-251. doi:10.1016/j.fcr.2011.06.017

Balvanera P, Pfisterer AB, Buchmann N et al (2006) Quantifying the evidence for biodiversity effects on ecosystem functioning and services. Ecol Lett 9:1146-1156. doi:10.1111/j.1461-0248.2006.00963.x

Bedoussac L, Justes E (2010a) Dynamic analysis of competition and complementarity for light and $\mathrm{N}$ use to understand the yield and the protein content of a durum wheat-winter pea intercrop. Plant Soil 330:37-54. doi:10.1007/s11104-010-0303-8

Bedoussac L, Justes E (2010b) The efficiency of a durum wheat-winter pea intercrop to improve yield and wheat grain protein concentration depends on N availability during early growth. Plant Soil 330:19 35. doi:10.1007/s11104-009-0082-2

Bennett EM, Peterson GD, Gordon LJ (2009) Understanding relationships among multiple ecosystem services. Ecol Lett 12:1394-1404. doi:10.1111/j.1461-0248.2009.01387.x

Bennett AJ, Bending GD, Chandler D, Hilton S, Mills P (2012) Meeting the demand for crop production: the challenge of yield decline in crops grown in short rotations. Biol Rev 87:52-71. doi:10.1111/j. 1469-185X.2011.00184.x

Berthet ETA, Bretagnolle V, Segrestin B (2014) Surmonter un blocage de l'innovation par la conception collective. Cas de la réintroduction de luzerne dans une plaine céréalière, Fourrages, 217, 13-21. http:// prodinra.inra.fr/record/264565

Betencourt E, Duputel M, Colomb B, Desclaux D, Hinsinger P (2012) Intercropping promotes the ability of durum wheat and chickpea to increase rhizosphere phosphorus availability in a low $\mathrm{P}$ soil. Soil Biol Biochem 46:21-33. doi:10.1016/j.soilbio.2011.11.015

Blazy J-M, Ozier-Lafontaine H, Doré T, Thomas A, Wery J (2009) A methodological framework that accounts for farm diversity in the prototyping of crop management systems. Application to bananabased systems in Guadeloupe. AgriSyst 101(1-2):30-41. doi:10. 1016/j.agsy.2009.02.004

Bogard M, Ravel C, Paux E, Bordes J, Balfourier F, Chapman S, Le Gouis J, Allard V (2014) Predictions of heading date in bread wheat (Triticum aestivum L.) using QTL-based parameters of an ecophysiological model. J Exp Bot. doi:10.1093/jxb/eru328

Boller BC, Nösberger J (1988) Influence of dissimilarities in temporal and spatial $\mathrm{N}$-uptake patterns on $15 \mathrm{~N}$-based estimates of fixation and transfer of $\mathrm{N}$ in ryegrass-clover mixtures. Plant Soil 112:167-175. doi:10.1007/BF02139992

Bommarco R, Kleijn D, Potts SG (2013) Ecological intensification: harnessing ecosystem services for food security. TREE 28:230 238. doi:10.1016/j.tree.2012.10.012
Brooker RW, Maestre FT, Callaway RM, Lortie CL, Cavieres LA, Kunstler G, Liancourt P, Tielborger K, Travis JMJ, Anthelme F, Armas C, Coll L, Corcket E, Delzon S, Forey E, Kikvidze Z, Olofsson J, Pugnaire FI, Quiroz CL, Saccone P, Schiffers K, Seifan M, Touzard B, Michalet R (2008) Facilitation in plant communities: the past, the present, and the future. J Eco 96(1):18-34. doi:10.1111/j.1365-2745.2007.01295.x

Bullock DG (1992) Croprotation. Critical Rev Plant Sci 11:309-326. doi: $10.1080 / 07352689209382349$

Burel F, Baudry J (1995) Species biodiversity in changing agricultural landscapes: a case study in the Pays d'Auge. France Agric Ecosyst Environ 55:193-200. doi:10.1016/0167-8809(95)00614-X

Caldwell MM, Dawson TE, Richards JH (1998) Hydraulic lift: consequences of water efflux from the roots of plants. Oecologia 113: 151-161. doi:10.1007/s004420050363

Callaway RM (1995) Positive interactions among plants. Bot Rev 61: 306-349. doi:10.1007/BF02912621

Cardinale BJ, Duffy JE, Gonzalez A, Hooper DU, Perrings C, Venail P, Narwani A, Mace GM, Tilman D, Wardle DA, Kinzig AP, Daily GC, Loreau M, Grace JB, Larigauderie A, Srivastava DS, Naeem S (2012) Biodiversity loss and its impact on humanity. Nature 486:59 67. doi:10.1038/nature11148

Cassman KG, Dobermann A, Walters DT, Yang H (2003) Meeting cereal demand while protecting natural resources and improving environmental quality. Ann Rev Energy Environ 28:315-358. doi:10.1146/ annurev.energy.28.040202.122858

Chenu K, Chapman SC, Tardieu F, McLean G, Welcker C, Hammer GL (2009) Simulating the yield impacts of organ-level quantitative trait loci associated with drought response in maize: a "gene-tophenotype"modeling approach. Genetics 183(4):1507-1523. doi: 10.1534/genetics.109.105429

Chesson P (2000) Mechanisms of maintenance of species diversity. Annu Rev Ecol Syst 31:343-366. doi:10.1146/annurev.ecolsys.31.1.343

Cook SM, Khan Z, Pickett JA (2007) The use of push-pull strategies in integrated pest management. Annu Rev Entomol 52(52):375-400. doi:10.1146/annurev.ento.52.110405.091407

Curl EA (1963) Control of plant disease by crop rotation. Bot Rev 29: 413-479. doi:10.1007/BF02860813

Dabney SM (1998) Cover crop impacts on watershed hydrology. J Soil Water Cons 53(3):207-213

Dabney SM, Delgado JA (2001) Using winter cover crops to improve soil and water quality. Commun Soil Sci Plant Anal 32(7\&8):12211250. doi:10.1081/CSS-100104110

Dawson TE (1993) Hydraulic lift and water use by plants: implications for water balance, performance and plant-plant interactions. Oecologia 95:565-574. doi:10.1007/BF00317442

Dawson JC, Goldringer I (2012) Breeding for genetically diverse populations: variety mixtures and evolutionary populations. Org Crop Breed 5:77-98. doi:10.1002/9781119945932.ch5

Deberdt P, Perrin B, Coranson-Baudu R, Duyick PF, Wicker E (2012) Effect of Allium fistulusum on Ralstonia solanacearum populations and tomato bacterial wilt. Plant Dis 96(5):687692

De Bello F, Lavorel S, Diaz S, Harrington R, Cornelissen J, Bargett R, Berg M, Cipriotti P, Feld CK, Hering D, Martins da Silva P, Potts S, Sandin L, Sousa JP, Storkey J, Wardle D, Harrison PA (2010) Towards an assessment of multiple ecosystem processes and services via functional traits. Biodivers Conserv 19:2873-2893

Deguine JP, Ferron P, Russell D (2008) Sustainable pest management for cotton production. A review. Agron Sustain Dev 28:113-137. doi: 10.1051/agro:2007042

Delmotte S, Lopez-Ridaura S, Barbier J-M, Wery J (2013) Prospective and participatory integrated assessment of agricultural systems from farm to regional scales: comparison of three modelling approaches. J Env Manag 129:493-502. doi:10.1016/ j.jenvman.2013.08.001 
Di HJ, Cameron KC (2002) Nitrate leaching in temperate agrosystems: source, factors and mitigating strategies. Nutr Cycl Agroecosyst 46: 237-256. doi:10.1023/A:1021471531188

Diaz S, Fargione J, Chapin FS, Tilman D (2006) Biodiversity loss threatens human well-being. PLoS Biol 4:1300-1305. doi:10. 1371/journal.pbio.0040277

Diaz S, Purvis A, Cornelissen JHC, Mace GM, Donoghue MJ, Ewers RM, Jordano P, Pearse WD (2013) Functional traits, the phylogeny of function, and ecosystem service vulnerability. Ecol Evol 3(9): 2958-2975. doi:10.1002/ece3.601

Dinnes DL, Karlen DL, Jaynes DB, Kaspar TC, Hatfield JL, Colvin TS, Cambardella CA (2002) Nitrogen management strategies to reduce nitrate leaching in tile-drained midwestern soils. Agron J 94:153171. doi:10.2134/agronj2002.1530

Doré T, Makowski D, Malezieux E, Munier-Jolain N, Tchamitchian M, Tittonell P (2011) Facing up to the paradigm of ecological intensification in agronomy: revisiting methods, concepts and knowledge. Europ J Agron 34:197-210. doi:10.1016/j.eja.2011. 02.006

Drinkwater LE, Wagoner P, Sarrantonio M (1998) Legume-based cropping systems have reduced carbon and nitrogen losses. Nature 396(6708):262-265. doi:10.1038/24376

Dukes JS (2001) Biodiversity and invasibility in grassland microcosms. Oecologia 126:563-568. doi:10.1007/s004420000549

Eigenbrod F, Armsworth PR, Anderson BJ, Heinemeyer A, Gillings S, Roy DB, Thomas CD, Gaston KJ (2012) The impact of proxy-based methods on mapping the distribution of ecosystem services. J Appl Ecol 47:377-385. doi:10.1111/j.1365-2664.2010.01777.x

Ekström G, Ekbom B (2011) Pest control in agro-ecosystems: an ecological approach. Crit Rev Plant Sci 30:74-94. doi:10.1080/07352689. 2011.554354

Fargione J, Tilman D (2005) Niche differences in phenology and rooting depth promote coexistence with a dominant $\mathrm{C} 4$ bunchgrass. Oecologia 143:598-606. doi:10.1007/s00442-005-0010-y

Finckh MR, Wolfe MS (2006) Diversification strategies. In The epidemiology of plant diseases. Springer 269-307.doi:10.1007/1-40204581-6_10

Finckh MR, Gacek ES, Goyeau H, Lannou C, Merz U, Mundt CC, Munk L, Nadziak J, Newton AC, de Vallavieille-Pope C, Wolfe MS (2000) Cereal variety and species mixtures in practice, with emphasis on disease resistance. Agronomie 20:813-837. doi: 10.1051/agro:2000177

Francis CA (1990) Potential of multiple cropping systems. In: Altieri MA, Hecht SB (eds) Agroecology and small farm development. CRC Press, Boca Raton, pp 137-150

Gaba S, Bretagnolle F, Rigaud T,Philippot L (2014) Managing biotic interactions for ecological intensification of agroecosystems. Front Ecol Evol, 2. doi: 10.3389/fevo.2014.00029

Gallais A (1970) Modèle pour l'analyse des relations d'associations binaires. Biom Praxim. 52-80

Ghaley BB, Hauggaard-Nielsen H, Hgh-Jensen H, Jensen ES (2005) Intercropping of wheat and pea as influenced by nitrogen fertilization. Nutr Cycl Agroecosyst 73:201-212. doi:10.1007/s10705-0052475-9

Giller KE, Witter E, Corbeels M, Tittonel P (2009) Conservation agriculture and smallholder farming in Africa: the heretics' view. Field Crop Res 114(1):23-34. doi:10.1016/j.fcr.2009.06.017

Gizlice Z, Carter TE, Burton JW, Emigh TH (1989) Partitioning of blending ability using two-way blends and component lines of soybean. Crop Sci 29(4):885. doi:10.2135/cropsci1989. 0011183X002900040008x

Gomez-Rodriguez O, Zavaleta-Mejia E, Gonzalez-Hernandez VA, Livera-Munoz M, Cardenas-Soriano E (2003) Allelopathy and microclimatic modification of intercropping with marigold on tomato early blight disease development. Field Crops Res 83:27-34. doi:10. 1016/S0378-4290(03)00053-4
Greaves MP, Marshall EJP. (1987) Field margins: definitions and statistics. In: Way, J.M., Greig-Smith, P.J. (Eds.), Field Margins. Monograph No. 35. British

$\mathrm{Gu}$ J, Yin X, Zhang C, Wang H, Struik PC (2014) Linking ecophysiological modelling with quantitative genetics to support marker-assisted crop design for improved yields of rice (Oryzasativa) under drought stress. Ann Bot 114:499-511. doi:10.1093/aob/mcu127

Haines-Young R, Potschin M. (2010). "The links between biodiversity, ecosystem services and human well-being," in ecosystem ecology: a new synthesis, eds. D. Raffaelli \& C. Frid. Cambridge University Press, Cambridge).

Hammer GL, van Oosterom E et al (2010) Adapting APSIM to model the physiology and genetics of complex adaptive traits in field crops. $\mathrm{J}$ Exp Bot 61(8):2185-2202. doi:10.1093/jxb/erq095

Hauggaard-Nielsen H, Jensen ES (2005) Facilitative root interaction in intercrops. Plant Soil 274:237-250. doi:10.1007/1-4020-4099-7_13

Hauggaard-Nielsen H, Gooding M, Ambus P, Corre-Hellou G, Crozat Y, Dahlmann C, Dibet A, Fragstein P, von Pristeri A, Monti M, Jensen ES (2009) Pea-barley intercropping for efficient symbiotic N2-fixation, soil $\mathrm{N}$ acquisition and use of other nutrients in European organic cropping systems. Field Crops Res 113:64-71. doi:10. 1016/j.fcr.2009.04.009

He Y, Ding N, Shi J, Wu M, Liao H, Xu J (2013) Profiling of microbial PLFAs: implications for interspecific interactions due to intercropping which increase phosphorus uptake in phosphorus limited acidic soils. Soil Biol Biochem 57:625-634. doi:10.1016/j. soilbio.2012.07.027

Hinsinger P, Betencourt E, Bernard L, Brauman A, Plassard C, Shen J, Tang X, Zhang F (2011) P for two, sharing a scarce resource: soil phosphorus acquisition in the rhizosphere of intercropped species. Plant Physiol 156:1078-1086. doi:10.1104/pp. 111.175331

Hoogenboom G, White JW, Messina CD (2004) From genome to crop: integration through simulation modeling. Field Crops Res 90(1): 145-163. doi:10.1016/j.fcr.2004.07.014

Hooper DU, Dukes JS (2004) Overyielding among plant functional groups in a long-term experiment. Ecol Lett 7:95-105. doi:10. 1046/j.1461-0248.2003.00555.x

Horlings LG, Marsden TK (2011) Towards the real green revolution? Exploring the conceptual dimensions of a new ecological modernisation of agriculture that could 'feed the world'. Global Environ Chang 21:441-452. doi:10.1016/j.gloenvcha. 2011.01.004

Isbell F, Calcagno V, Hector A, Connolly J, Harpole W, Reich P, SchererLorenzen M, Schmid B, Tilman D, van Ruijven J, Weigelt A, Wilsey BJ, Zavaleta ES, Loreau M (2011) High plant diversity is needed to maintain ecosystem services. Nature 477(7363):199-202. doi:10. 1038/nature10282

Jarecki MK, Lal R (2003) Crop management for soil carbon sequestration. Crit Rev Plant Sci 22:471-502. doi:10.1080/713608318

Jones GA, Sieving KE (2006) Intercropping sunflowers in organic vegetables to augment avian predators of arthropod pests. Agric Ecosyst Environ 117:171-177. doi:10.1016/j.agee.2006.03.026

Jumpponen A, Hogberg P, Huss-Danell K, Mulder CPH (2002) Interspecific and spatial differences in nitrogen uptake in monocultures and two-species mixtures in north European grasslands. Funct Ecol 16(4):454-461. doi:10.1046/j.1365-2435.2002.00642.x

Kahmen A, Renker C, Unsicker SB, Buchmann N (2006) Niche complementarity for nitrogen: an explanation for the biodiversity and ecosystem functioning relationship? Ecology 87(5):1244-1255. doi:10.1890/0012-9658(2006)87[1244:ncfnae]2.0.co;2

Kirkegaard JA, Conyers MK, Hunt JR, Kirkby C, Watt M, Rebetzke GJ (2014) Sense and nonsense in conservation agriculture: principles, pragmatism and productivity in Australian mixed farming systems. Agric Ecosyst Environ 187:133-145. doi:10.1016/j. agee.2013.08.011 
Knott EA, Mundt CC (1990) Mixing ability analysis of wheat cultivar mixtures under diseased and nondiseased conditions. Theoret Appl Gene 80(3):313-320. doi:10.1007/BF00210065

Körner C, Stocklin J et al (2008) Small differences in arrival time influence composition and productivity of plant communities. New Phytol 177(3):698-705. doi:10.1111/j.1469-8137.2007. 02287.x

Lamondia J, Elmer WH, Mervosh TL, Cowles RS (2002) Integrated management of strawberry pests by rotation and intercropping. Crop Prot 21:837-846. doi:10.1016/S0261-2194(02)00050-9

Lavorel S, Garnier E (2002) Predicting changes in community composition and ecosystem functioning from plant traits: revisiting the Holy Grail. Funct Ecol 16:545-556. doi:10.1046/j.1365-2435.2002. 00664.x

Lavorel S, Grigulis K, Lamarque P, Colace M-P, Garden D, Girel J, Douzet R, Pellet G (2011) Using plant functional traits to understand the landscape-scale distribution of multiple ecosystem services. J Ecol 99:135-147. doi:10.1046/j.1365-2435.2002.00664.x

Le Gal PY, Merot A, Moulin CH, Navarrete M, Wery J (2010) A modelling framework to support farmers in designing agricultural production systems. Env Model Soft 25:258-268. doi:10.1016/j. envsoft.2008.12.013

Leibold MA (1995) The niche concept revisited: mechanistic models and community context. Ecology 76(5):1371-1382. doi:10.2307/ 1938141

Letort VR, Mahe P, Cournède PH, de Reffye P, Courtois B (2008) Quantitative genetics and functional-structural plant growth models: simulation of quantitative trait loci detection for model parameters and application to potential yield optimization. Ann Bot 101(8): 1243-1254. doi:10.1093/aob/mcm197

Li L, Li SM, Sun JH, Zhou LL, Bao XG, Zhang HG, Zhang FS (2007) Diversity enhances agricultural productivity via rhizosphere phosphorus facilitation on phosphorus-deficient soils. PNAS 104:1119211196. doi:10.1073/pnas.0704591104

Li YF, Ran W, Zhang RP, Sun SB, Xu GH (2009) Facilitated legume nodulation, phosphate uptake and nitrogen transfer by arbuscular inoculation in an upland rice and mung bean intercropping system. Plant Soil 315:285-296. doi:10.1007/s11104-008-9751-9

Lithourgidis AS, Dordas CA, Damalas CA, Vlachostergios DN (2011) Annual intercrops: an alternative pathway for sustainable agriculture. Austr J Crop Sci 5:396-410, ISSN: 1835-2693

Lopez CG, Mundt CC (2000) Using mixing ability analysis from twoway cultivar mixtures to predict the performance of cultivars in complex mixtures. Field Crops Res 68(2):121-132. doi:10.1016/ S0378-4290(00)00114-3

Louarn G, Corre-Hellou G et al (2010) Déterminants écologiques et physiologiques de la productivité et de la stabilité des associations graminées-légumineuses. Innov Agronom 11:79-99

Lynch JP (2013) Steep, cheap and deep: an ideotype to optimize water and $\mathrm{N}$ acquisition by maize root systems. Ann Bot 112(2):347-357. doi:10.1093/aob/mcs293

Mace GM, Norris K, Fitter AH (2012) Biodiversity and ecosystem services: a multi-layered relationship. TREE 27(1):19-26. doi:10. 1016/j.tree.2011.08.006

Malézieux E, Crozat Y, Dupraz C, Laurans M, Makowski D, OzierLafontaine H, Rapidel B, Tourdonnet S, de Valantin-Morison M (2009) Mixing plant species in cropping systems: concepts, tools and models. a review. Agron Sustain Dev 29:43-62. doi:10.1051/ agro:2007057

Mann LK (1986) Changes in soil carbon after cultivation. Soil Sci 142: 279-288. doi:10.3334/CDIAC/tcm.007

Marshall EJP, Moonen C (2002) Field margins in northern Europe: their functions and interactions with agriculture. Agric Ecosyst Environ 89:5-21

Marshall EJP, West TM, Kleijn D (2006) Impacts of an agri-environment field margin prescription on the flora and fauna of arable farmland in different landscapes. Agric Ecosyst Environ 113:36-44. doi:10. 1016/S0167-8809(01)00315-2

Millennium Ecosystem Assessment (2005) Ecosystems and human wellbeing: synthesis. World Resources Institute, Washington, DC

Miranda Filho JB, Chaves LJ (1991) Procedures for selecting composites based on prediction methods. Theor Appl Genet 81:265-271. doi: 10.1007/BF00215732

Motisi N, Montfort F, Faloya V, Lucas P, Dore T (2009) Growing Brassica juncea as a cover crop, then incorporating its residues provides complementary control of Rhizoctonia root rot of sugar beet. Field Crop Res 113:238-245. doi:10.1016/j.fcr.2009.05.011

Mundt CC (2002) Use of multiline cultivars and cultivar mixtures for disease management. Annu Rev Phytopathol 40(1):381-410. doi: 10.1146/annurev.phyto.40.011402.113723

Nagendra H, Reyers B, Lavorel S (2013) Impacts of land change on biodiversity: making the link to ecosystem services. Curr Opin Environ Sustain 5(5):503-508. doi:10.1016/j.cosust.2013.05.010

Naidoo R, Ricketts TH (2006) Mapping the economic costs and benefits of conservation. PLoS Biol 4:e360. doi:10.1371/journal.pbio.0040360

Nibouche S, Tibère R, Costet L (2012) The use of Erianthus arundinaceus as a trap crop for the stem borer Chilo sacchariphagus reduces yield losses in sugarcane: preliminary results. Crop Prot 42: 10-15. doi:10.1016/j.cropro.2012.06.003

Ogenga-Latigo MW, Ampofo JKO, Balidawa CW (1992) Influenceof maize row spacing on infestation and damage of intercropped beans by the bean aphid (Aphis fabae). Field Crop Res 30:110-122. doi: 10.1016/0378-4290(92)90061-D

Pang J, Wang Y, Lambers H, Tibbett M, Siddique KHM, Ryan MH (2013) Commensalism in an agroecosystem: hydraulic redistribution by deeprooted legumes improves survival of a droughted shallow-rooted legume companion. Physiol Plant 149:79-90. doi:10.1111/ppl.12020

Pelzer E, Bazot M, Makowski D, Corre-Hellou G, Naudin C, Al Rifaï M, Baranger E, Bedoussac L, Biarnès L, Boucheny P, Carrouée B, Dorvillez D, Foissy D, Gaillard B, Guichard L, Mansard MC, Omon B, Prieur L, Yvergniaux M, Justes E, Jeuffroy M-H (2012) Pea-wheat intercrops in low-input conditions combine high economic performances and low environmental impacts. Eur J Agron 40:39-53. doi:10.1016/j.eja.2012.01.010

Peoples MB, Brockwell J, Herridge DF, Rochester IJ, Alves BJR, Urquiaga S, Boddey RM, Dakora FD, Bhattarai S, Maskey SL, Sampet C, Rerkasem B, Khan DF, Hauggaard-Nielsen H, Jensen ES (2009) The contributions of nitrogen-fixing crop legumes to the productivity of agricultural systems. Symbiosis $48(1-3): 1-17$. doi: 10.1007/BF03179980

Pirgozliev SR, Edwards SG, Hare MC, Jenkinson P (2003) Strategies for the control of Fusarium head blight in cereals. Eur J Plant Pathol 109:731-742. doi:10.1023/A:1026034509247

Potts SG, Biesmeijer JC, Kremen C, Neumann P, Schweiger O, Kunin WE (2010) Global pollinator declines: trends, impacts and drivers. TREE 25:345-353. doi:10.1016/j.tree.2010.01.007

Poveda K, Gomez ML, Martinez E (2008) Diversification practices: their effect on pest regulation and production. Rev Colomb Entomol 34: $131-144$

Prudent M, Lecomte A, Bertin N, Causse M, Génard M (2011) Combining ecophysiological modelling and quantitative trait loci analysis to identify key elementary processes underlying tomato fruit sugar concentration. J Expe Bot 62:907-919. doi:10.1093/ $\mathrm{jxb} / \mathrm{erq} 318$

Rapidel B, Traoré BS, Sissoko F, Lançon J, Wery J (2009) Experimentbased prototyping to design and assess cotton management systems in West Africa. Agron Sustain Dev 29:545-556. doi:10.1051/agro/ 2009016

Ratnadass A, Fernandes P, Avelino J, Habib R (2012) Plant species diversity for sustainable management of crop pests and diseases in agroecosystems: a review. Agron Sustain Dev 32:273-303. doi:10. 1007/s13593-011-0022-4 
Ratnadass A, Blanchard E, Lecompte P (2013) Ecological interactions within the biodiversity of cultivated systems. In: Cultivating biodiversity to transform agriculture. Hainzelain ed., ed Quae, Cirad, 141-179

Raynaud X, Jaillard B, Leadley PW (2008) Plants may alter competition by modifying nutrient bioavailability in rhizosphere: a modeling approach. Am Nat 171:44-58. doi:10.1086/523951

Reymond M, Muller B, Leonardi A, Charcosset A, Tardieu F (2003) Combining quantitative trait loci analysis and an ecophysiological model to analyze the genetic variability of the responses of maize leaf growth to temperature and water deficit. Plant Physiol 131(2): 664-675. doi:10.1104/pp. 013839

Ripoche A, Celette F, Cinna J-P, Gary C (2010) Design of intercrop management plans to fulfill production and environmental objectives in vineyards. Eur J Agron 32(1):30-39. doi:10.1016/j.eja. 2009.05.005

Robertson GP, Swinton SM (2005) Reconciling agricultural productivity and environmental integrity: a grand challenge for agriculture. Front Ecol Envi 3(1):38-46. doi:10.1890/1540-9295(2005) 003[0038:RAPAEI]2.0.CO;2

Rodriguez-Cabana R, Kloepper JW (1998) Cropping systems and the enhancement of microbial activities antagonistic to nematodes. Nematropica 28:144

Sekiya N, Yano K (2004) Do pigeon pea and sesbania supply groundwater to intercropped maize through hydraulic lift? Hydrogen stable isotope investigation of xylem waters. Field Crops Res 86:167-173. doi:10.1016/j.fcr.2003.08.007

Sekiya N, Araki H, Yano K (2011) Applying hydraulic lift in an agroecosystem: forage plants with shoots removed supply water to neighboring vegetable crops. Plant Soil 341:39-50. doi:10.1007/ s11104-010-0581-1

Shelton AM, Badenes-Perez FR (2006) Concepts and applications of trap cropping in pest management. Ann Rev Entomol 51:285-308. doi: 10.1146/annurev.ento.51.110104.150959

Smith JG (1976) Influence of crop background on aphids and other phytophagous insects on Brussels sprouts. Ann Appl Biol 83:113. doi:10.1111/j.1744-7348.1976.tb01689.x

Sokos CK, Mamolos AP, Kalburtji KL, Birtsas PK (2013) Farming and wildlife in Mediterranean agroecosystems. J Nat Cons 21:81-92. doi:10.1016/j.jnc.2012.11.001

Suding KN, Lavorel S, Chapin FS, Cornelissen JHC, Diaz S, GarnierE GD, Hooper DU, Jackson ST, Navas ML (2008) Scaling environmental change through the community-level: a trait-based responseand-effect framework for plants. Glob Chang Biol 14:1125-1140. doi:10.1111/j.1365-2486.2008.01557.x

Tilman D (1990) Mechanisms of plant competition for nutrients: the elements of a predictive theory of competition. In: Grace JB,
Tilman D (eds) Perspectives on plant competition. Academic, New York, pp 117-141. doi:10.1016/0169-5347(90)90112-Q

Tilman D (1999) Global environmental impacts of agricultural expansion: the need for sustainable and efficient practices. PNAS 96(11): 5995-6000. doi:10.1073/pnas.96.11.5995

Tilman D, Fargione J, Wolff B, D'Antonio C, Dobson A, Howarth R, Schindler D, Schlesinger WH, Simberloff D, Swackhamer D (2001) Forecasting agriculturally driven global environmental change. Science 292(5515):281-284. doi:10. 1126/science. 1057544

Tilman D, Cassman KG, Matson PA, Naylor R, Polasky S (2002) Agricultural sustainability and intensive production practices. Nature 418(6898):671-677. doi:10.1038/nature01014

Tournebize R (1995) Water relations in a shrub-grass intercrop and comparison with pure stand. In: Sinoquet $\mathrm{H}$ and Cruz P (Eds) Ecophysiology of tropical intercropping. pp 189-1996

Trenbath BR (1993) Intercropping for the management of pests and diseases. Field Crops Res 34:381-405. doi:10.1016/03784290(93)90123-5

Vannette RL, Fukami T (2014) Historical contingency in species interactions: towards niche-based predictions. Ecol Lett 17(1):115-124. doi:10.1111/ele.12204

Vickery JA, Feber RE, Fuller RJ (2009) Arable field margins managed for biodiversity conservation: a review of food resource provision for farmland birds. Agric Ecosyst Environ 133(1-2):1-13. doi:10.1016/ j.agee.2009.05.012

von Gillhaussen P, Rascher U, Jablonowski ND, Plückers C, Beierkuhnlein C et al (2014) Priority effects of time of arrival of plant functional groups override sowing interval or density effects: a grassland experiment. PLoS ONE 9(1):e86906. doi:10.1371/ journal.pone.0086906

Wackers FL, Romeis J, van Rijn P (2007) Nectar and pollen feeding by insect herbivores and implications for multitrophic interactions. Ann Rev Entomol 52:301-323. doi:10.1146/annurev.ento.52.110405. 091352

Walter U, Hermann D, Hurle K (1993) Set-aside: effects of rotational fallow on slugs, nematodes and cereal foot root diseases. Gesunde Pflanzen 45:207-216

West TO, Post WM (2002) Soil organic carbon sequestration rates by tillage and crop rotation. Soil Sci Soc Am J 66:1930-1946. doi:10. 2136/sssaj2002.1930

Yeates GW (1987) How plants affect nematodes. Adv Ecol Res 17:61113. doi:10.1016/S0065-2504(08)60244-5

Zhu Y, Chen H, Fan J, Wang Y, Li Y, Chen J, Fan J, Yang S, Hu L, Loung H, Mow TW, Teng PS, Wang Z, Mundt CC (2000) Genetic diversity and disease control in rice. Nature 406(6797):718-722. doi:10. $1038 / 35021046$ 